\title{
Microscopic morphology and histochemistry of the digestive system of a tropical freshwater fish Trichomycterus brasiliensis (Lütken) (Siluroidei, Trichomycteridae)
}

\author{
Ciro Alberto de Oliveira Ribeiro ${ }^{1}$ \\ Edith Fanta ${ }^{1}$
}

\begin{abstract}
The digestive system of Trichomycterus brasiliensis (Lütken, 1874), a small sized tropical Teleostean fish widely distributed in South America, was studied. Tissue samples were prepared for light and scanning electron microscopy (SEM). Trichomycterus brasiliensis shows stratified esophagus epithelium with taste buds and goblet cells with neutral and acid mucus at the anterior region. The stomach is caecal, presenting a pyloric valve with neutral mucus cells. At the terminal portion it is surrounded by a thick muscular wall. The intestine shows two loops; the epithelium is single columnar, with acid and neutral mucus in goblet cells. Multicellular intestinal glands are absent. Granular cells are often seen in the mucosa, less in the submucosa but were not observed in the muscularis. After the intestine-rectal valve, the rectum shows lower mucosal folds, more goblet cells and a thicker muscularis. No lobes were observed at the liver. Small regions of pancreatic tissue may be identified within the hepatic tissue mainly surrounding vessels and ducts. A compact pancreas may also be observed ventrally to the stomach and covering the bile duct. The possible significance of the heterogeneous character of the digestive tube mucosubstances is discussed. The digestive system of $T$. brasiliensis presents structural characteristics of a predator fish. KEY WORDS. Teleostei, digestive tube, histology
\end{abstract}

The gastrointestinal tract of fishes is well developed and structurally adapted to accommodate a wide variety of feeding habits, varying in gross structure and length (HOAR et al. 1979).

The esophagus of teleost fishes, connects the pharynx with the stomach or with the intestine. Its only function seems to provide lubrication, and its physiological importance has been neglected (MEISTER et al. 1983). Recent histological and histochemical studies have suggested that the posterior esophageal epithelium in some marine and freshwater teleost species may function in osmoregulation (HuMBERT et al. 1984). The esophageal epithelium may be simple or stratified (AL-HUSSAINI 1949a; REIFEL \& TRAVILL 1977; Sis et al. 1979; MARTIN \& BLABER 1984; MURRAY et al. 1994). Ciliated cells lining the esophagus of Barbus sarana (Hamilton, 1822) were detected by MosHIN (1962). Nevertheless, according to DZHUMALIYEV (1982), it seems that the esophagus epithelium is not related to the nature of food. The abundance of mucous cells in the esophagus suggests an adaptation to a varied diet (GodinHo et al. 1970); in Pimelodidae (PIGNALBERI et al. 1973) and in Pleuronectes americanus (Walbaum, 1792) and P. ferruginea (Storer, 1839) (MURRAY et al. 1994)

1) Departamento de Biologia Celular, Universidade Federal do Paraná. Caixa Postal 19031, 81531-970 Curitiba, Paraná, Brasil. E-mail: ciro@garoupa.bio.ufpr.br 
The fish stomach has been defined as a widening of the intestine i.e., an intestinal bulb by PICTET (1909) and ROGiCK (1931), because of the absence of gastric glands and a similar epithelium, in both regions (KHANNA 1971; GAUTHIER \& LANDIS 1975; SinHA \& MoITRA 1974; Verma \& TYAgi 1974; ReIFEL \& Travill 1979; Chaves \& VAzZoler 1984). However, the stomach may also be classified as a true organ as it may have two distinct histological regions: the anterior cardic region with gastric glands and the posterior pyloric region without gastric glands (DALELA 1969; YADAV \& SINGH 1980; ROMBOUT \& TAVERNE-THILE 1982; ULIBARRIE 1982; MARTIN \& BLABER 1984; MURRAY et al. 1994).

The post-gastric alimentary canal (BARRINGTON 1957; KAPOOR et al. 1975; MORRISON 1987; MURRAY et al. 1996), has a primary importance in the digestion and absorption of dietary nutrients (MURRAY et al. 1996). The intestine lumen is lined by a simple columnar epithelium interspersed by goblet cells (REIFEL \& TRAVILL 1979). The other layers of the intestine are: submucosa, muscularis (longitudinal and circular) and serosa and they vary with species. The mucosal histology and the number and type of specific cell types varies according to the fishes diet (KUPERMAN \& KUZ'MAINA 1994). The ileo-rectal valve is not present in all fishes, but the separation of the medium and posterior intestine may be identified as a sphincter (MOSHIN 1962), although ALL-HuSSAINI $(1946,1947)$ previously referred the putative function of the structure. The rectum separated from the intestine by a valve was described by DAWES (1929) and the absence of an ileo-rectal valve is related to the absence of a posterior intestine or rectum in many species (PASHA \& KAMAL 1964).

The liver of teleost fish is compact and lies in the first third of the abdominal cavity. It can be unilobed, multilobed, without distinct lobes or with irregular pattern of cells (PIGNALBERI et al. 1973; UliBARRIE 1982; RochA et al. 1994). The pancreas may be found extending along the mesentery blood vessels, near to the bile ducts, around the gallbladder, close to the hepatic ducts, inside the liver, or among pyloric caecaes (HALE 1965; LANGER et al. 1979; ROMBOUT \& TAVERNE-THIELE 1982). The pancreas of teleosts, has exocrine cells as well as endocrine cells that are organized as islets of Langerhans or Brockman's bodies (RENNIE 1903; BOLDYREFF 1935; YASUTAKE \& WALES 1983; LiMA et al. 1991).

Teleostean goblet cells are known to contain carbohydrates (REIFEL \& TRAVILL 1979) without characterizing their specific nature. An abundance of mucous cells indicates that esophageal mucosubstances have some role in the digestive process (REIFEL \& TRAVILL 1977), and different mucosubstances found in different regions of the gut are correlated with assorted digestive functions (MURRAY et al. 1996).

Our study has the aim to describe the digestive system of Trichomycterus brasiliensis (Lütken, 1974) and to correlate structural and histochemical characteristics to the fish diet. On the other hand, T. brasiliensis and T. zonatus (Eiguman, 1918) have been recently used for studies of toxicity tests (OLIVEIRA-RIBEIRO et al. 1995, 1996a,b; OLIVEIRA-RIBEIRO \& TORRES 1995) and the need was felt for a morphological baseline knowledge on those organic systems that are involved in the absorption of some chemicals that are ingested through contaminated food. 


\section{MATERIAL AND METHODS}

Adult specimens of Trichomycterus brasiliensis (Fig. 1) were collected in Piedade do Rio Grande, Minas Gerais state, Brazil. The fish were held in stock glass tanks with dechlorinated tap water for a minimum of 20 days and fed three times a week. The water temperature was kept at $22 \pm 2^{\circ} \mathrm{C}$ (s.d.) and with constant aeration. Twenty six adult specimens were used for histology, histochemistry and scanning electron microscopy (SEM). The esophagus, stomach, intestine and rectum, pancreas and liver were individually sampled. For histology and histochemistry the tissues were fixed in Bouin's aqueous fluid for a minimum of 12 hours and

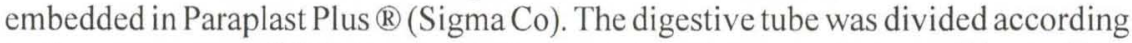
to BARRINGTON (1957) in an anterior part (esophagus and stomach), medium intestine (intestine loops I and II) and posterior intestine or rectum. Sections were cut at 5 to $7 \mu \mathrm{m}$ and stained with either Haematoxilin-Eosin (HE), Mallory's trichrome and Masson's trichrome. For carbohydrate histochemistry the sections were stained with periodic acid-shiff (PAS) for identification of neutral glycoconjugates like 1:2 glycol groups; Alcian blue ( $\mathrm{pH} 2.5$ ), for carboxylated and some sulfated glycoconjugates; Alcian blue ( $\mathrm{pH} 1.0$ ), for sulfated glycoconjugates; and Alcian yellow ( $\mathrm{pH} 2.5)$ together with Alcian blue $(\mathrm{pH} 1.0)$ to detect simultaneously acid carboxylated and sulfated glycoconjugates. The positive and negative controls were made using PAS, with acetilation by pyridine $\left(60^{\circ} \mathrm{C}, 24\right.$ hours $)$ and amylase. For Alcian Blue and Alcian Yellow metilation $\left(60^{\circ} \mathrm{C}, 5\right.$ hours $)$ was used. For SEM the samples were fixed in glutaraldehyde $3 \%$ buffered in cacodilate $0.2 \mathrm{M}$ at $\mathrm{pH} 7.2$ for 24 hours at room temperature, dehydrated in a graded series of ethanol $(50,70,90$, 95 and $3 \mathrm{X}$ at $100 \%$, for 10 minutes in each bath), critical point dried with liquid $\mathrm{CO}_{2}$, and finally, covered with gold. Pictures were obtained with an Olympus PM10AD Photomicroscopy and a Philipps SEM 505.

\section{RESULTS}

\section{Gross Anatomy}

In this study parts of the digestive system anterior to the transverse septum (i.e. the buccal cavity and pharynx) will not be considered.

Trichomycterus brasiliensis presents a wide but short tubular esophagus that runs from the posterior end of the pharynx to the anterior cardic region of the stomach, being ventrally overlapped by the liver.

The stomach is J-shaped and of caecal type, long and divided in gastric and pyloric regions. The gastric region, is longer, and has a small diameter. The pyloric region turns left and extends towards the beginning of the intestine tube. $T$. brasiliensis does not present pyloric caeca. There is a well-developed constriction separating the pyloric region from the intestine (loop I).

The ileo-rectal valve is present but without external constriction. From the point where it emerges it runs back ventrally to the gastric region of the stomach, forming the loop I. There, in the mid-line, it turns back over itself forming the loop II up to the ileo-rectal valve. Ventrally, just posterior the valve begins the rectum, that ends at the anus situated in front of the anal fin. 

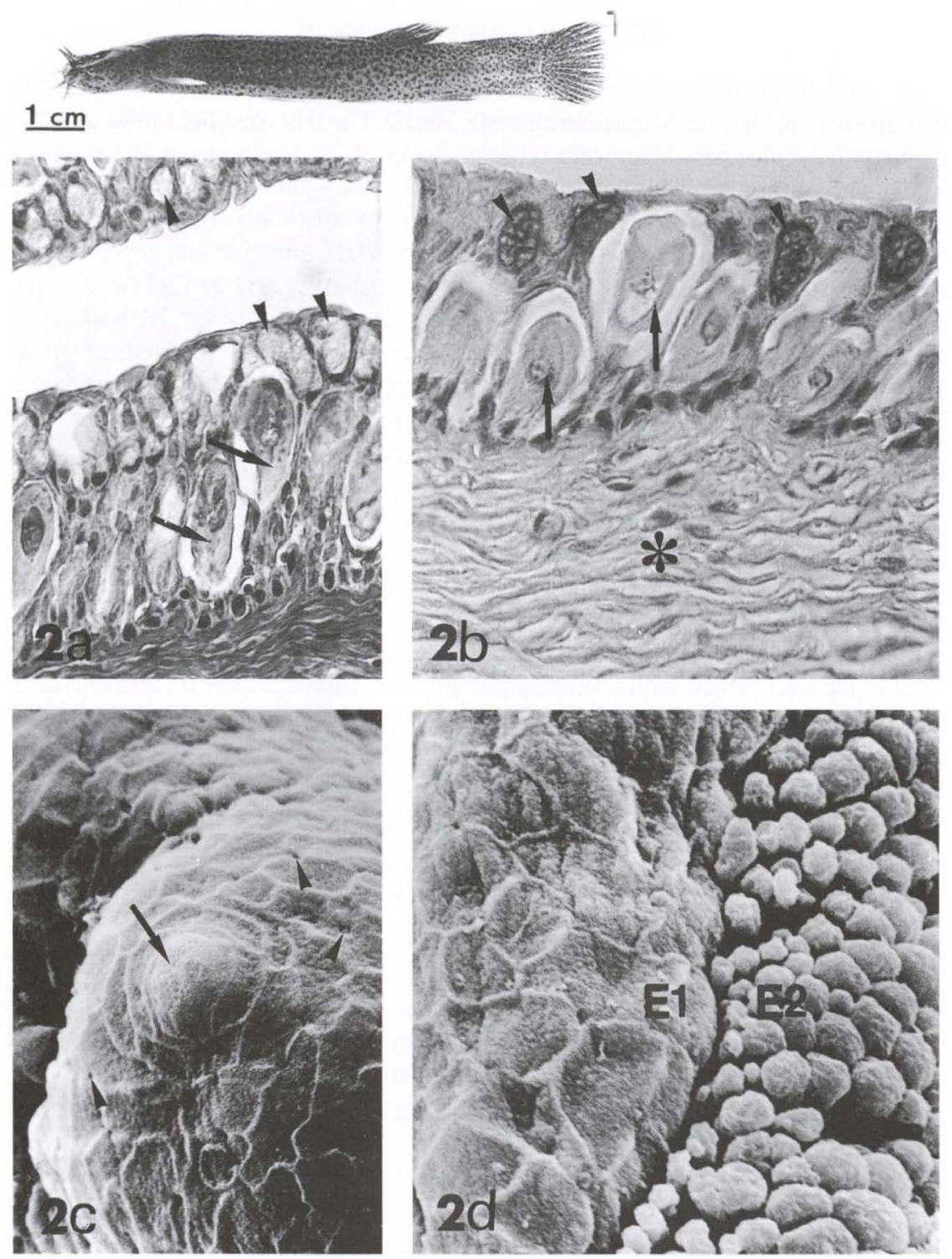

Figs 1-2. (1) Trichomycterus brasiliensis; (2a) esophagus of Trichomycterus brasiliensis. Notice the stratified epithelium, the club cells with shrinken cytoplasm (arrows) and the goblet cells (arrowheads). (2b) Observe the large layer of connective tissue under the mucosa $\left({ }^{*}\right)$, the club cells (arrows) and the goblet cells with acidic mucus (arrowheads); (2c) View of the mucosal surface of the esophagus by SEM. Observe the taste bud (arrow), the nickered boundaries of epithelial cells and the pore-like outlets of goblet cells (arrows head); (2d) transition between esophagus (E1) and stomach (E2). Scanning Electron Microscopy, H/E. 
The liver does not present lobes, and is located in the first portion of a celomatic cavity covering ventrally the esophagus. The pancreas is diffuse, inside the liver and in the mesenteries, but a compact pancreas may be observed lying ventrally to the stomach, covering the bile duct. The latter opens on the anterior portion of the intestinal loop I.

\section{Histology and Histochemistry}

\section{Esophagus and Stomach}

The esophagus has three concentric tissue layers: mucosa, submucosa and muscularis. The mucosal epithelium is stratified squamous with goblet cells near to the surface (Fig. 2a). At the anterior region of the organ, goblet cells are intensively stained with Alcian blue (Fig. 2b), but have only a slightly positive reaction to PAS (Tab. I). The apex of goblet cells often are deeper than the epithelial surface, between polygonal cells (Fig. 2c). Some roundish and prominent taste buds occur in the anterior region of the oesophagus, at the apex of folds. A high density of Club cells occurs at the basal region of the epithelium. These cells are elongated, and larger than goblets cells, always have a centrally placed nucleus. They seem to be attached to the basal layer and are never found at the surface of the epithelium. Their contents are weakly stained by periodic acid-Schiff (Fig. 2b).

Table I. Summary of goblet cells from different regions of the digestive tube and liver of Trichomycterus brasiliensis. Degree of stanining: (3) intense, (2) moderate, (1) weak, (0) absent. Color abbreviation: (B) blue, (BN) blue-black, (BP) blue-purple, (PR) purple-red, (R) red, (BY)blue-yellow, (YB) yellow-blue (REIFEL \& TRAVILL 1977).

\begin{tabular}{|c|c|c|c|c|c|c|}
\hline Goblet cell & PAS & $\mathrm{Ab} \mathrm{pH} 2.5$ & $\mathrm{AB} \mathrm{pH} 1.0$ & $\mathrm{AB} \mathrm{pH} 2.5+\mathrm{PAS}$ & $\mathrm{AB} \mathrm{pH} 1.0+\mathrm{AY} \mathrm{pH} 2.5$ & 5 Cytochemical Interpretation \\
\hline Oesophagus & 2-PR & $3-\mathrm{BN}$ & 1-B & 2-BP & $1-B Y$ & $\begin{array}{l}\text { Sialomucin (some weakly } \\
\text { sulfomucin) } \\
\text { Neutral mucosubstances }\end{array}$ \\
\hline Stomach & 3-PB & 0 & 0 & 0 & 0 & Neutral mucosubstances \\
\hline Intestine & & & & & & Sialomucin \\
\hline Loop I and II & $1-R$ & $3-\mathrm{BN}$ & $2-B$ & 2-BP & $2-B Y$ & $\begin{array}{l}\text { Strongly acidic sulfomucin } \\
\text { Weakly neutral } \\
\text { mucosubstances }\end{array}$ \\
\hline Rectum & 2-PR & $2-B$ & $1-B$ & 1-PB & 1-BY & $\begin{array}{l}\text { Acidic sulfomucin (some } \\
\text { weakly sialomucin) } \\
\text { Neutral mucosubstances }\end{array}$ \\
\hline Liver & 2-PR & 0 & 0 & 0 & 0 & Glycogen \\
\hline Amylase & 0 & 0 & 0 & 0 & 0 & Control \\
\hline
\end{tabular}

The esophagus displays approximately twelve parallel folds arranged longitudinally. The folds are deep and involve both the mucosa and submucosa. The muscularis consists of skeletal muscle oriented in all directions at the anterior part of the organ. The skeletal muscles are replaced gradually by a thinner layer of a non oriented smooth muscle layer in the posterior region of the organ.

The transition from esophagus to stomach is sharp. The stratified squamous epithelium of the esophagus is continuous with a single columnar epithelium in the 
stomach and the epithelium surface also changes abruptly from one region to the other (Fig. 2d). In the stomach, there are different types of glands. In the anterior region of the stomach there are small secondary projections from the primary folds and crypts or simple tubular glands (Fig. 3a). In the single tubular glands at the gastric region, there are cells secreting neutral mucus distributed around the gland aperture (Fig. 3c), differing from the cells described to esophagus. This structure is found only at the cardic region of the organ, at the pyloric region, all cells within the tubular glands are PAS positive (Fig. 3d). The surface pattern for both regions is the same. Glands are present on the whole organ (Fig. 3b,e), but those observed at the pyloric region are deeper and have a higher mucous production than those of the gastric region (Fig. 3e). In the anterior proximal region there is no mucous secretion. Mucous secreting cells in the glands are more frequent closer to the pylorus, where the glands are formed exclusively by mucous secreting cells (Tab. I; Fig. 3e,f).

The submucosa is well developed in the stomach and the lamina propria surrounds the epitelial glands. In the pyloric region thick projections from lamina propria form the folds (Fig. 3d). The muscle layer in the proximal cardic region of the stomach is single, comprised by circularly arranged muscle cells. At the distal cardic region the muscular layer is thicker and has two distinct layers: the thick inner circular layer and the thin outer longitudinal muscular layer. In the pyloric region the inner circular layer increases in thickness and the outer longitudinal layer remains unchanged (Fig. 3f). The serosa along the whole stomach, the medium intestine and the rectum is a thin dense connective tissue limited by a single layer of flat mesothelial cells.

\section{Intestine}

The pyloric valve in Trichomycterus brasiliensis is a projection of the submucosa and of the inner muscle layer, separating the stomach from the intestine. In this region the cells of the inner circular layer of the muscularis change their direction, running towards the lumen of the organ, towards the rectum. At the intestinal wall, the muscular cells become organized again (Fig. 4a). The valve is a projection towards the lumen of the organ (Fig. 4c), where an abrupt change on the epithelial cells takes place (Fig. 4b,c,d).

The medium intestine has two loops (I and II), and is formed by four types of tissues: mucosa, submucosa, muscularis and serosa (Fig. 5a). The mucosal epithelium is single columnar with cylindrical absorptive cells, bearing a brush border (Fig. 5a,c). There are also numerous goblet cells scattered along the two loops (Fig. 6a,b). Goblet cells in the loops I and II show a strong positive reaction for neutral and carboxylated acid mucus, and a weak reaction for sulphated acid mucus (Tab. I; Fig. 5b,c,e). Some cells have acid mucus secretion at the basal region and neutral secretion at the apical region, and others are only acid or only neutral mucus secreting cells. Some granular cells or macrophage (SIRE \& VERNIER 1992) are identified in the epithelium, presenting large granules in the cytoplasm. They are grouped mainly close to the epithelial base but occur also in the apical region (Fig. $5 \mathrm{~d})$. In the rectum the number of granular cells is apparently smaller than that described in loops I and II. The medium intestine and the rectum of Trichomycterus brasiliensis lack a muscularis mucosal and glands other than goblet cells.

Revta bras. Zool. 17 (4): 953 - 971, 2000 

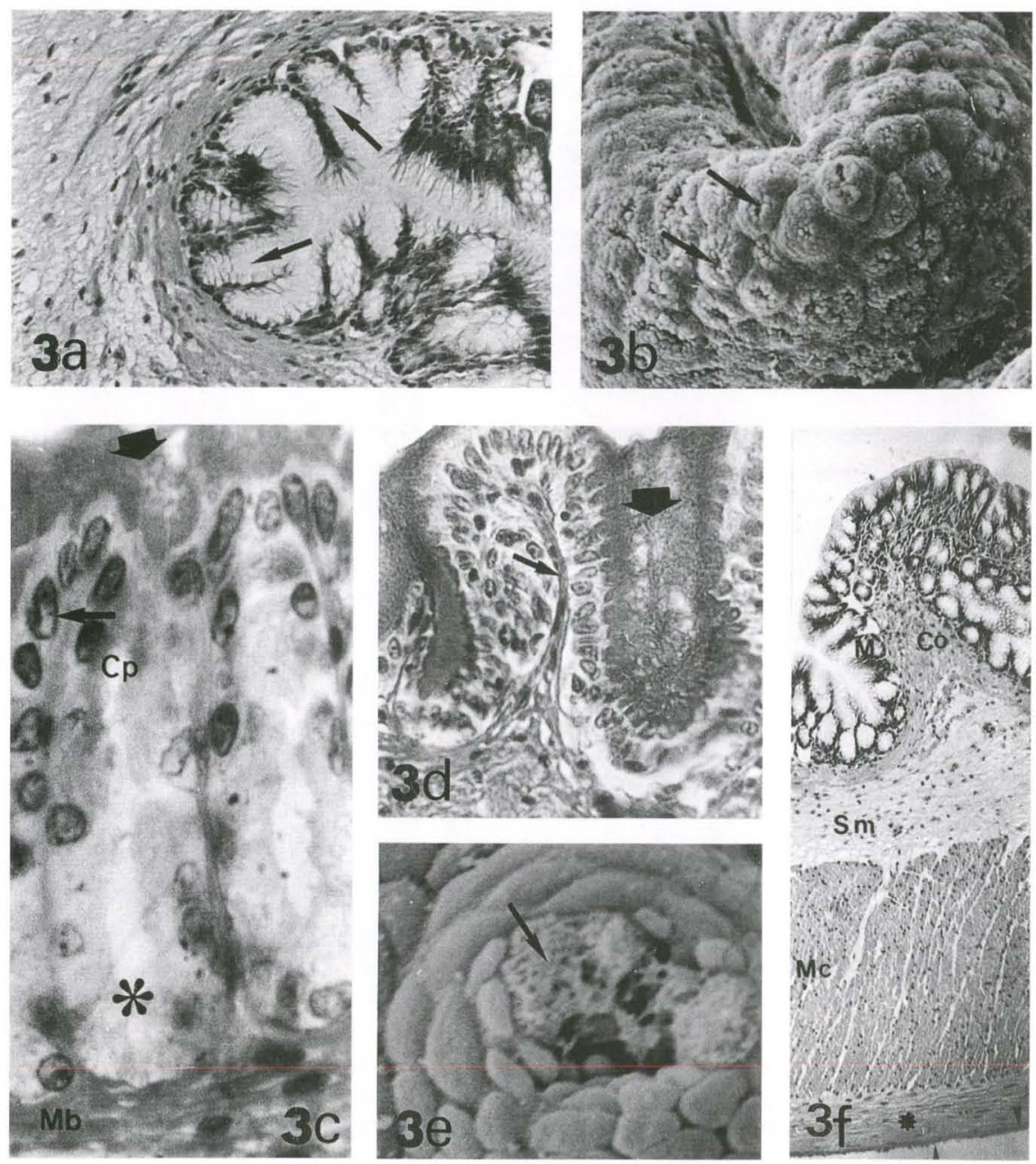

Fig. 3. (a) Stomach of Trichomycterus brasiliensis. Partial view of the mucosa from the anterior region of the stomach with tubular glands (arrows). (b) Mucosal surface from the anterior region of the stomach showing a fold with opening of pits (arrows); (c) detail of the mucosa from the anterior region of the stomach. Notice the tubular gland and a positive PAS reaction, only in the cells around the outlet of the gland (big arrow), mucous cell (small arrow), gland lumen $(\mathrm{Cp})$, cells in the basal region of the gland with negative PAS reaction $\left({ }^{*}\right)$; (d) detail of the mucosa pyloric region. Notice positive PAS reaction in whole gland (big arrow). The small arrow shows the thin projections from lamina propria, forming the glands walls; (e) detail of the mucus released from glands in the pyloric region of the stomach (arrow); (f) concentric tissue layers from stomach pyloric region: mucosa $(\mathrm{M})$, submucosa $(\mathrm{Sm})$, inner circular layer or the muscularis externa (Mc), outer longitudinal Layer of the muscularis externa (MI) and serosa (arrowheads). 

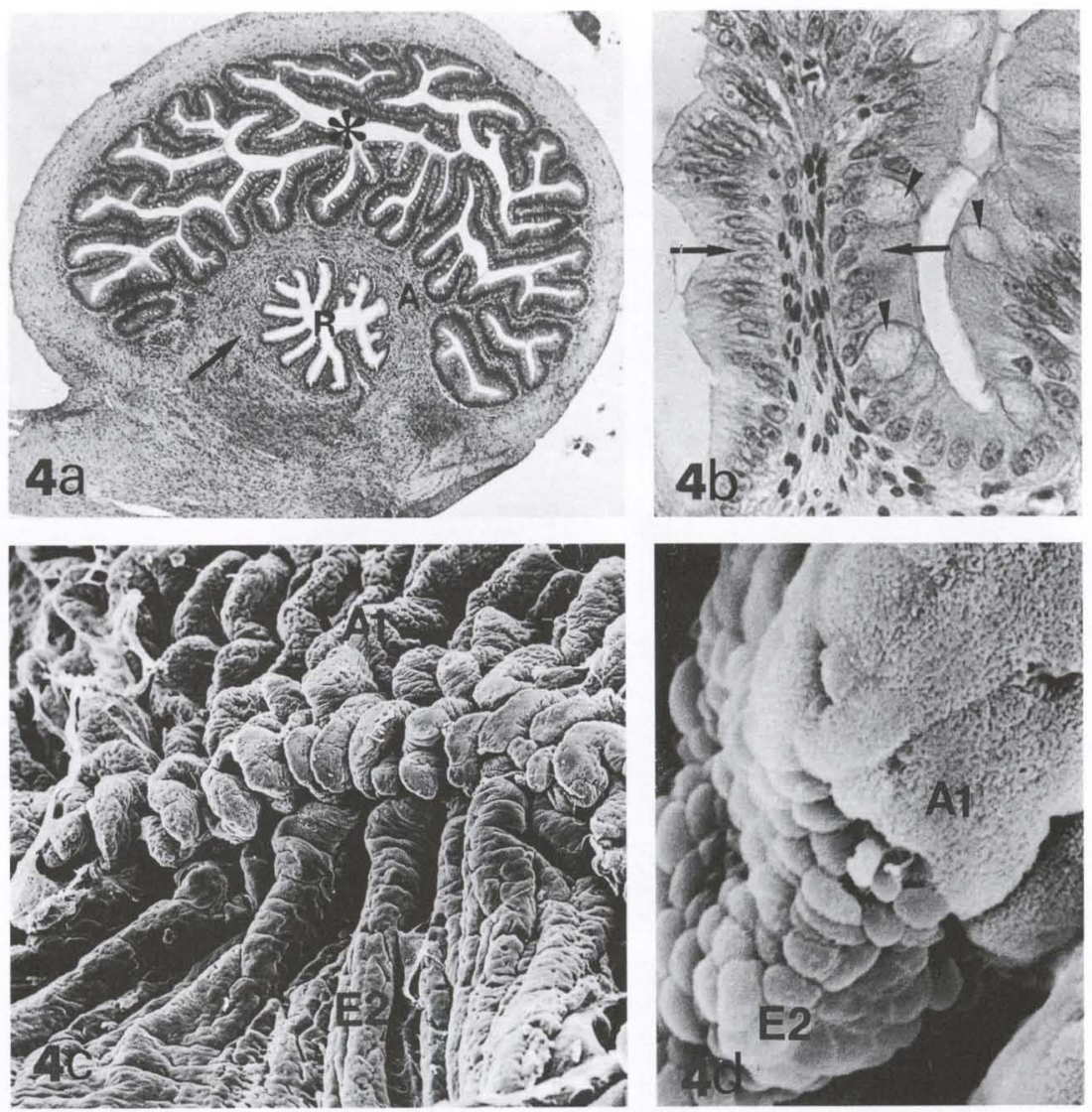

Fig. 4. (a) Medium intestine in the pyloric valve region of Trichomycterus brasiliensis. Cross section of the pyloric valve. Notice the projection of the submucosa and inner layer of the muscularis externa (arrow) into the lumen of the intestine to form the pyloric valve (A). (R) represents the lumen of the valve and $\left(^{*}\right)$ the medium intestine region; (b) detail of the pyloric valve epithelium at the transitional region between stomach (left arrow) and medium intestine (right arrow). Notice the presence of the first goblet cells in the intestinal epithelium (arrowheads) and the abrupt change of the epithelial cells; (c) partial view by SEM of the pyloric valve region. Stomach $(E 2)$ and medium intestine $(A 1)$; (d) detail of the pyloric valve transition region. Notice the abrupt change on the epithelial surfaces. (E2) stomach epithelial surface and (E1) intestinal epithelial surface.

The submucosa is thin and rich in blood vessels, and the lamina propria invades the primary and secondary folds in the whole organ (Fig. 5a). In the rectum the lamina propria is not clearly separated from the corion and the folds are not deep, bearing less secondary folds (Fig. 6a). The muscularis externa is the thickest layer of the medium intestine and the rectum. It consists of a thick inner circular layer and a thinner outer longitudinal layer thoughout the organ (Fig. 5a,b). Close to the 
anus, the circular layer becomes thicker forming the anal sphincter. Through SEM, only at loop II and the rectum is possible to observe clear limits of epithelial cells and a great number of goblet cells on epithelial surfaces, what is not the case for loop I (Fig. 5e).
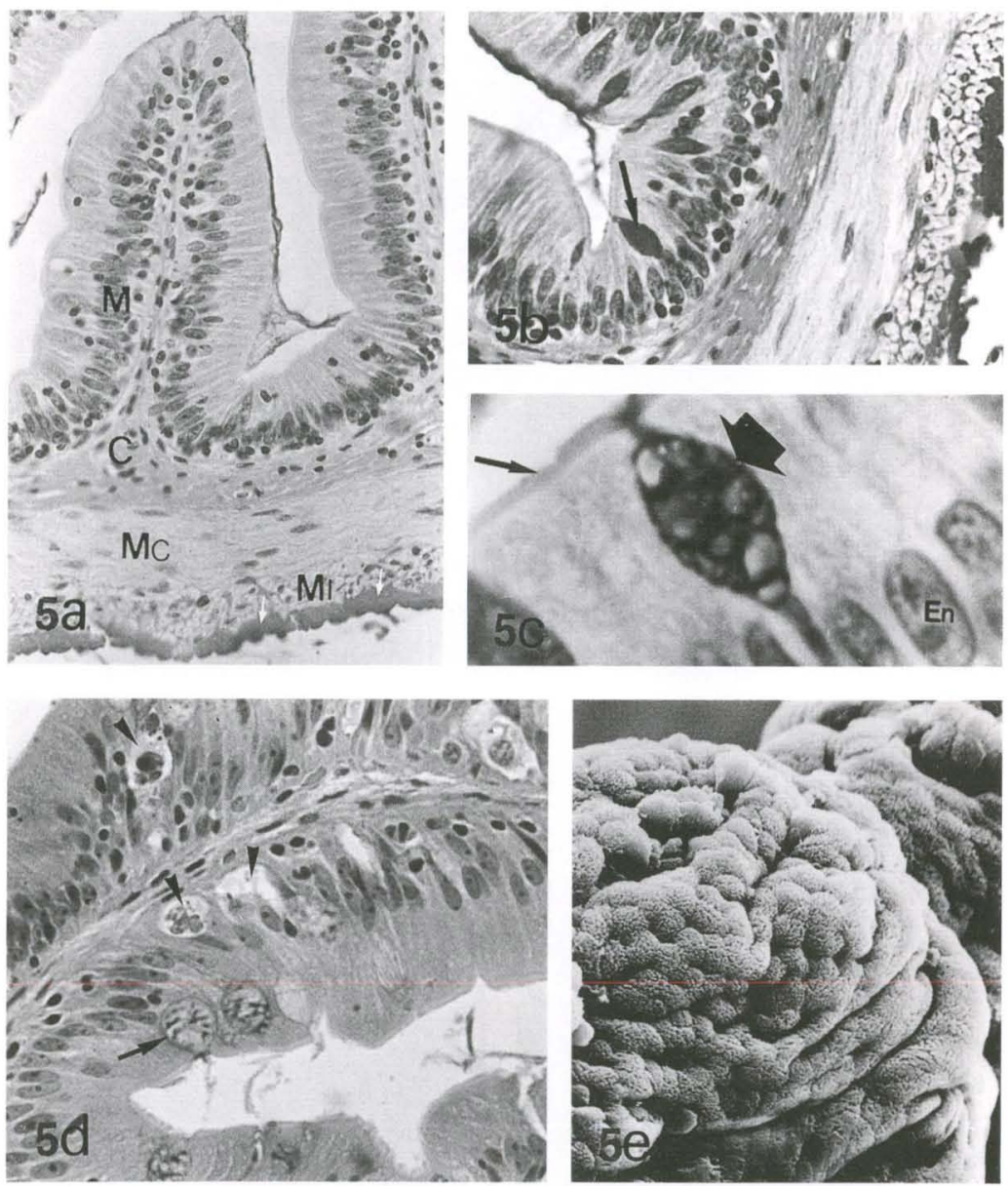

Fig. 5. (a) Medium intestine of Trichomycterus brasiliensis. Cross section in loop I region. Observe the layers: mucosa $(M)$, lamina propria and underlying connective tissue $(C)$ inner circular layer of the muscularis (Mc), muscularis externa (MI) and serosa (arrow). The arrowheads point to the brush border. (b) Partial cross section from intestine (loop I) showing the acidic mucosubstances of goblet cells (arrow); (c) detail of the intestinal mucosa (loop II) showing the acidic mucosubstances in a goblet cell (big arrow). Note brush border (small arrow) and the nucleus (EN) of one of the enterocytes; (d) partial cross sectional view of a secondary fold showing the granular cells (arrowheads) and the apical region of a goblet cell displaying a weak reaction for acidic mucus (arrow). (e): SEM view of an irregular mucosal surface on fold of the medium intestine (loop II). 
The ileo-rectal valve (Fig. 6a,b) is a projection of the internal circular muscular layer, displayed towards the rectum in rectal direction, forming a thick fold that separates the loop II from rectum. The epithelium lining the valve has the same characteristics thoughout the whole intestine.
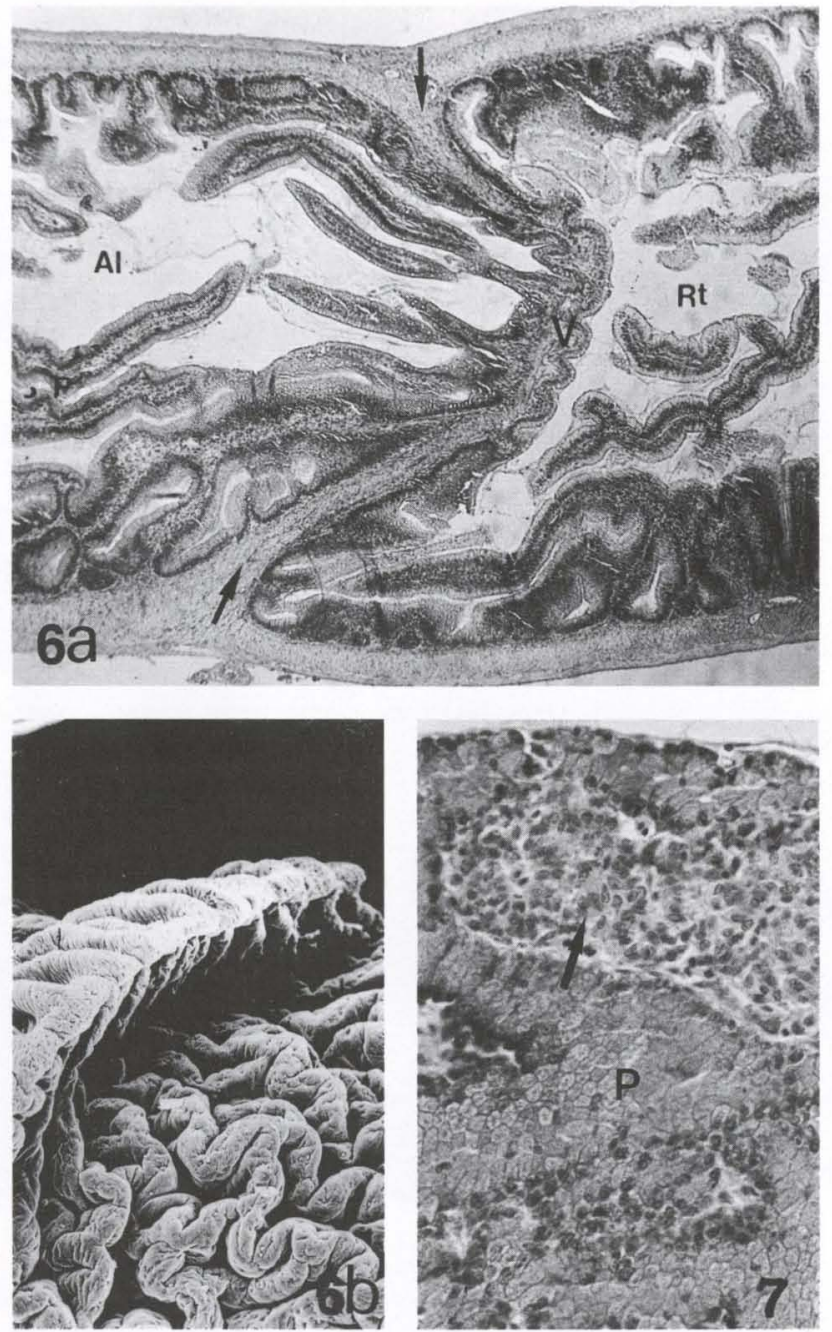

Figs 6-7. (6a) Ileo-rectal valve region of Trichomycterus brasiliensis longitudinal section showing the projection of the inner layer of the muscularis extern to form the valve (arrows). Valve (V), medium intestine lumen (AI) and rectum lumen (RT); (6b) scanning partial view of the ileo-rectal valve. Note the projection of the valve in an aboral direction. (7) Histological section of the compact pancreatic tissue located ventrally along the stomach. Note the large islet of Langerhan (arrow) and the exocrine cells (P). 


\section{Liver and Pancreas}

The liver lies in the anterior third of the abdominal cavity and has an irregular shape. It has no lobes and is lined by the serosa. The hepatocytes are polyhedral, with granular cytoplasm. Their nuclei are spherical and centrally located presenting well delineated nucleoli. The tissue shows many blood vessels, some portal areas, and dispersed bile ducts. Some regions of the hepatic cells are weakly positive to the periodic acid-Schiff, due to some glycogen stored in their cytoplasm.

The pancreas is mainly diffuse and exocrine pancreatic cells are seen around the larger vessels. Endocrine tissue is organized as Langerhan's islets and exocrine serous cells arranged as acini, forming the parenchyma scattered within the omentum (Fig. 7). A thin layer of compact pancreatic tissue, not easily seen macroscopically, lies along the ventral surface of the stomach, and near the extra-hepatic bile duct and some great vessels, reaching the loop I of the medium intestine.

\section{DISCUSSION}

Biodiversity in tropical freshwater bodies is high but many fish species are almost unknown. For most of them a baseline of morphological knowledge is not yet established. This requires, among others, a histological research, and was the reason for the study that was done on Trichomycterus brasiliensis, an important species in most of South America. The digestive tract description and feedings habits in fishes provides useful ecological and biological information to be use in future research. Nevertheless the digestive tract of $T$. brasiliensis shows many similarities to that of other taxonomically related fishes.

Although ANDERSON (1986) reported no clear esophagus function in the digestion of food in Girella tricuspidata (Quoy \& Gaimard, 1824); the esophagus epithelium has been correlated to variations in the natural diet in the family Radidae (F.A. Verigina 1970 in litt.). Although there is no clear esophagus function in the digestion food for T. brasiliensis, it seems possible that the acidic nature of its secretion may provide a suitable chemical environment for possible digestive function. This has also been proposed by REIFEL \& TRAVILL (1977) and ANDERSON (1986) in G. tricuspidata. The lack of distinction between the lamina propria and the submucosa observed in the esophagus of Pleuronectes americanus and $P$. ferruginea by MURRAY et al. (1994), was also found for T. brasiliensis and according to REIFEL \& TRAVILL (1977), it may be associated with the absence of a muscularis mucosae. The stratified epithelial cells decribed for T. brasiliensis, have been reported by MurRAY et al. (1994) in P. americanus and $P$. ferruginea and according to HIRJII (1983) as a support for the globlet cells. Some authors have suggested that the chemically variable mucus produced by esophageal goblet cells may have a role in digestion (REIFEL \& TRAVILL 1977; HIRJII 1983). According to MURRAY et al. (1994), it seems plausible to suggest that a secondary mucin or enzyme of surface origin may combine with goblet cell mucus to provide a digestive function for the esophagus. Despite the great number of goblet cells described by Godinho et al. (1970) and Pignalberi et al. (1973), respectively in Pimelodus maculatus (Lacèpede, 1803) and P. albicans (Valenciennes, 1840), no specific 
function of these cells was suggested. Although we have found a great diversity in the mucosubstances produced in the esophagus of Trichomycterus brasiliensis, different from that observed by MURRAY et al. (1994), our morphological and histochemical studies could not conclude about their chemical interference in the digestion of the food before the stomach. It suggests, however, an adaptation to facilitate a fast ingestion of different types of preys, also described by GoDINHO et al. (1970) and PignAlberi et al. (1973) in Pimelodidae and MURRAY et al. (1994) in Pleuronectes americanus and P. ferruginea. Neutral and acid mucus esophagic secreting cells that occurs in T. brasiliensis, were also described by OLIVEIRA \& Silva (1971) in Cichla ocellaris (Block \& Schneider, 1801), by PIGNALBERY et al. (1973) in P. albicans, by GodinHo et al. (1970) in P. maculatus, and by SIS et al. (1979) in Ictalurus punctatus (Rafinesque, 1818). According to GromaN (1982), generally, teleost esophageal mucous cells have been noted to contain at least two types of nonsuphated acid mucus, sulphated acid mucus, or neutral mucus.

The presence of taste buds in the anterior region of the esophagus resemble a similar condition described by GodiNHO et al. (1970) for Pimelodus maculatus, by Claudhy \& Khandelwal (1961) for Orienus plagiostomus (MacClelland, 1842), by SIS et al. (1979) for I. punctatus and by MARTIN \& BLABER (1984) for the family Ambassidae. In T. brasiliensis the number of taste buds is comparatively small and they are concentrated on the anterior region of the organ. Probably here they are involved in the food orientation to the stomach, possibly with a last possibility of food selection, once the main selection has been done within the buccopharingeal cavity.

The thick layer of connective tissue between the mucosa and the muscle cells, as well as the deep longitudinal folds found in T. brasiliensis will probably help to reinforce and maintain the integrity of the walls of the organ when a great amount of food is ingested at one time or when preys are swallowed as a whole (MURRAY et al. 1994). According to REIFEL \& TRAVILL (1977) the randomly dispersed skeletal muscle fibers as described for $T$. brasiliensis, have been found in other teleosts and may serve as reinforcement to subjected to violent extension by ingestion of live fish. Although the muscularis of the mucosa has not been found in T. brasiliensis, it was reported for example in Petromyzon marinus (Linnaeus, 1758) by HANSEN \& YOUSON (1978). The esophagus of $T$. brasiliensis has no precisely oriented muscle, but bundles of muscle are dispersed along the entire esophagus, different from described in G. tricuspidata by ANDERSON (1986) and in Ictalurus punctatus by Sis et al. (1979), while MURRAY et al. (1994) describe a longitudinal bundles of muscle and circular muscle in Pleuronectes ferruginea as observed in T. brasiliensis.

Although MAGID (1975) has described a gradual transition on the epithelium from the esophagus to the stomach in Polypterus senegalus (Curvier, 1829), the abrupt transition observed in T. brasiliensis was also described for Pimelodus maculatus (GodinHo et al. 1970), Pimelodus albicans (PIGNAlBeri et al. 1973), Gadus morhua (Linnaeus, 1758) (MoRRISON 1987), Seriola dumerili (Risso, 1810) (Grau et al. 1992) and Pleuronectides (MURRAY et al. 1994).

The histological studies of the alimentary channel across species of fish are not rare and are becoming more valuable as the interest in fish culture expands and more information is required with regard to feeding and nutrition (MURRAY et al. 1994). 
The classification of the regions of the stomach as gastric or pyloric in this work, is based upon the presence of gastric glands in the anterior portion of the stomach and their absence in the posterior region, also used by MosHIN (1962), AGRAWAL \& SHARMA (1965), SRIWASTWA (1970), and MARTIN \& BLABER (1984). Gastric glands are described for many fishes that are bottom feeders (BISHOP \& ODENSE 1966), and they were also related to digestion time, and to carnivorous and voracious feeding (MOSHIN 1962). MURRAY et al. (1994) described two distinct regions in the stomach of Pleuronectes americanus and P. ferruginea: a cranial glandular or cardic stomach and a caudal aglandular or pyloric stomach. The different cellular zones associated with the cardic region reported by the same author, was not observed in Trichomycterus brasiliensis. The secretion of neutral mucosubstances found in T. brasiliensis, only at the entrance of the gastric glands and in all cells of the pyloric glands was detected also by BISHOP \& ODENSE (1966), DALELA (1969) and Sis et al. (1979) and described as mucous neck cells by MURRAY et al. (1994) in Pleuronectes americanus and $P$. ferruginea. Although the same authors have described variations in mucous histochemistry between zones in the same species, our histochemical results did not detected differences of mucous released at the stomach surface. The mucus in the stomach is believed to help in the conduction of food and to provide efficient protection under different gastric conditions (MURRAY et al. 1994). According to OSMAN \& CACECI (1991), besides protecting the mucosa, these mucins also regulate the $\mathrm{pH}$ of the gastric fluid, explaining the variations in the gastric fluid $\mathrm{pH}$ in different species with different diets.

A thin wall, well supplied by blood vessels, in the median region of the stomach in Lepidocephalus guntea (Hamilton, 1822) was described by YADAV \& SINGH (1980) and was also observed in T. brasiliensis. A very well developed muscular layer in the pyloric region of the stomach and compact connective tissue observed immediately below the gland, observed in L. guntea was also observed in Trichomycterus brasiliensis. MURRAY et al. (1994) suggests that the median region of the stomach described for Pleuronectides, has a great elasticity and tensile strength, and according to SRIWASTWA (1970) it is characteristic for voracious fish that display considerable digestive activity. The muscularis externa associated with the stomach of $T$. brasiliensis is comparable to that observed in other species, exhibiting an inner circular layer of smooth muscle and a thinner outer longitudinal layer in close association with the thin serosa (MORRISON 1987; GRAU et al. 1992; MURRAY et al. 1994). The pyloric valve described for Gasterosteus aculeatus (Linnaeus, 1758) by HALE (1965), resembles the pyloric valve identified for $T$. brasiliensis. In other species such as Gadus morhua, the valve is replaced by a sphincter (BISHOP \& ODENSE 1966). CLARKE \& WiTCOMB (1980) and MURRAY et al. (1994) described a thickened inner circular layer of smooth muscle in the pyloric region in association with the formation of the pyloric sphincter. A well developed muscular pyloric valve found in $T$. brasiliensis, suggests that this structure is able to control the exit of the food toward the intestine.

The Lieberkühn glands observed in the intestine of Pimelodus maculatus (GODINHO et al. 1970) and in some species of Gadidae (BISHOP \& ODENSE 1966) do not occur in T. brasiliensis. The presence of goblet cells and the absence of Lieberkühn 
glands in the intestine of fish (KOROVINA et al. 1991; MURRAY et al. 1994) reinforce the statement of AL-HUSSAINI (1949a) that the intestinal epithelium of teleosts is the simplest among the vertebrates. About the granular cells found in T. brasiliensis, GREENE (1912) attributed to them the secretion of lipase, but AL-HusSAINI (1949b) described a positive reaction for alkaline phosphatase and glycogen. These cells appear in the rectum of Notenigonus crisolucos (Mitchill, 1814) (REIFEL \& TRAVILL 1979) and of Ictalurus punctatus (KREMENTZ \& CHAPMAN 1975). Apparently they were also associated with defense mechanisms, since they are frequently found in nodules formed by the presence of ectoparasites (CHAICHARN \& BULLOCK 1967) and SIRE \& VERNIER (1992) have associated them with macrophages.

In Trichomycterus brasiliensis a great amount of folds were observed in loop I of the intestine, increasing the surface area, and enhancing the absorptive activity, typical for carnivorous species (KHANNA 1971). The columnar cells presenting a basal nucleus, a very eosinophilic cytoplasm, and an apical brush border observed in this specie are common in teleosts. The folded intestinal mucosa, covered with villi, composed of an epithelial layer supported by connective tissue of the lamina propria-submucosa was also described for Hippoglossus hippoglossus (Linnaeus, 1758), Pleuronectes americanus and P. ferruginea (MURRAY et al. 1994). The compact tissue in $T$. brasiliensis seems an unusually dense colagenous lamina propria, probably functioning as extra epithelial support for a large intestinal tract and as an adaptation to handle a diet of large fish. The muscularis externa consisting of an outer longitudinal, and a thicker inner circular layer of smooth muscle, was described for three species of pleuronectides by MURRAY et al. (1994) and is similar to that in other vertebrates, having been also found in T. brasiliensis. The thick inner circular muscle layer was comparable to that of $P$. platessa (DAwES 1929), Ambassis sp. (MARTIN \& BlabER 1984) and P. americanus and P. ferruginea (MURRAY et al. 1994). According to GRAU et al. (1992), the thickness of the muscularis may be correlated with the temporary storage in and expulsion of faecal material from this area. This characteristic of $T$. brasiliensis, was also found in Ilisha filigera (Valencienes, 1847) (KhanNa 1971) and Poecila sp. (CACECI \& Hrubec 1990). A sphincter that divides the median intestine from the rectum was described by MosHin (1962) for various species. The ileo-rectal valve was classified by SoKOLOV et al. (1986) as a pre-rectal valve, because, as far as the posterior intestine may be called rectum, there is no need for the existence of an ileum. According to the same author the rectum may be distinguished from the median intestine by the presence of simple folds and well developed circular musculature. The absence of an ileo-rectal valve is characterized also by an absence of a rectum (PASHA \& KAMAL 1964). At the level of loop I in the median intestine the bile is released, showing once more that this is the region of the intestine with higher digestive and absorptive activity. KUPERMAN \& KUZ'MAINA (1994), studying fishes with different types of feeding habits, suggested that the degree of increase in the digestive and transportive surface of the intestine to the microvilli may differ. According to MURRAY et al. (1996) different mucosubstances have been correlated with assorted digestive function. Neutral substances combined with alkaline phosphate assist in the digestion and emulsification of food (CLARKE \& WITCOMB 1980). GRAU et al.

Revta bras. Zool. 17 (4): 953 - 971, 2000 
(1992), suggested that the presence of neutral mucins may indicate absorptive functions and ANDERSON (1986) reported that mucosubstances may provide cofactors required for the breakdown of food. The present Cytochemical evidence and the morphological descriptions, suggests that the loop I in Trichomycterus brasiliensis intestine tube, is the most important area for nutrients absorption. According to MURRAY et al. (1996), mucus chemo-types may not be an interspecies constant and its digestive role may be an important factor to consider when discussing digestive physiology nutrition and diet development in different species.

An increase in the number of goblet cells in the rectum observed by SEHGAL \& SALARIA (1970) in Cirrhina mrigala (Bloch, 1795) and KHANNA (1971) in Tor tor (Hamilton, 1822) and MURRAY et al. (1996) in Pleuronectides, was also described for T. brasiliensis, and implies the need for increased mucosa protection and lubrication for faecal expulsion. The presence of a large number of mucous secreting cells provides a mucous layer around the fecal pellet, facilitating its release and protecting the epithelium, as also described by AL-HussaINI (1949a), SINHA \& MOITRA (1974) and MURRAY et al. (1996). This was visually observed in live T. brasiliensis. According to GRAU et al. (1992), the thickening of the muscularis has been correlated with the temporary storage in and expulsion on faecal material from this area.

Histologically, the lobules in teleosts liver are not as well defined as they are in livers of higher vertebrates. Their outlines are diffuse, but they were readily described by SIMON et al. (1967). Although HAMPTON et al. (1989) have described a curvilinear and circular arrays of hepatocytes and a lack of apparent lobulation for Salmo gairdneri (Walbaum, 1792), the liver in Trichomycterus brasiliensis is very similar to that described for Striped Bass [Morone saxatilis (Walbaum, 1792)] by GROMAN (1982) and for Salmonids by YASUTAKE \& WALES (1983). According to ROCHA et al. (1994, 1995), there are no discernible lobules or acini in trout liver, and no established nomenclature exists for all the histological features of fish liver. The absence of portal triads and tracts in T. brasiliensis have also been observed in other species (HAMPTON et al. 1987; HAMPTON et al. 1989; ROBERTSON \& BRADLEY 1992; ROCHA et al. 1995). As observed in T. brasiliensis, most Osteichthyes have groups of pancreatic cells in the liver (DALELA 1969; GROMAN 1982; YASUTAKE \& WALES 1983; HAMPTON et al. 1987).

According to YASUTAKE \& WALES (1983) the pancreas tissue in many teleosts is diffused throughout the adipose tissue that surrounds the pyloric caeca. The pancreas was classified by KRISTAL (1946) as diffuse when it occurs around vessels, gallbladder, and in the mesentery; or compact. Both types are seen in $T$. brasiliensis and were also detected by SINHA (1958), HALE (1965) and ULIBARRIE (1982). In T. brasiliensis particularly large islets of Langerhans were found in the compact pancreatic tissue under the stomach, and was also described in Morone saxatilis by GROMAN (1982). In compact pancreas LiMA et al. (1991) have described the presence of Brockmann bodies (Langerhans Islands) in Pacú. A similar structure was found in T. brasiliensis and in other species reported by other authors (RENNIE 1903; BOLDYREFF 1935; YASUTAKE \& WALES 1983).

The determination of the cellular structures along the digestive tube helps to equate all feeding possibilities for this species which sometimes are insufficiently 
answered through direct observations. With the present study, it becomes clear that Trichomycterus brasiliensis is not only a predator, but is able to ingest varied whole, large and live preys. Therefore their important position in the food chain and consequent role in the ecosystem is revealed.

ACKNOWLEDGEMENTS. Financial supported was provided by $\mathrm{CNPq}$ and CAPES. The authors are grateful to the Electron Microscopy Center of the Federal University of Paraná for technical assistance. The editorial assistance of Dr. Helena Kavall was greatly appreciated.

\section{REFERENCES}

Agrawal, V.P. \& V. Sharma. 1965. Morpho-histological studies of the digestive tract of Mystus vittatus (Bloch.). Proc. Nat. Acad. Sci. 36: 441-456

AL-HussAINI, A.H. 1946. The anatomy and histology of the alimentary tract of the bottom-feeder, Mulloides auriflamma (Forks). Jour. Morphol. 78: 121-154.

-1947. The anatomy and histology of the plankton-feeder, Atherina forskali (Rupp). Jour. Morphol. 80: 251-286.

- 1949a. On the functional morphology of the alimentary tract of some fish in relation to differences in their feeding habit: anatomy and histology. Quant. Jour. Microsc. Soc. 90: 109-140.

-1949b. On the functional morphology of the alimentary tract of some fish in relation to differences in their feeding habits cytology and physiology. Quant. Jour. Microsc. Soc. 90: 323-354.

ANDERSON, T.A. 1986. Histological and cytological structure of the gastrointestinal tract of the luderick, Girella tricuspidata (Pisces, Kyphosidae) in relation to diet. Jour. Morphol. 190: 109-119.

Barrington, E.J.W. 1957. The Physiology of Fishes, p. 109-161. In: M.E. BROWN (Ed.). Alimentary canal and digestion. New York, Academic Press.

Bishop, C. \& P.H. OdENSE. 1966. Morphology of the digestive tract on the cod Gadus morhua. Fish Res. Board Can. 23: 1607-1615.

BolDYREFF, E.B. 1935. A microscopic study of the pancreas in fishes; especially those of the orders Haplomi and Cyprinodontes. Copeia 1: 23-24.

CACECI, T. \& T.C. Hrubec. 1990. Histology and ultrastructure of the gut of the black Mollie (Poecilia spp.), a hybrid teleost. Jour. Morphol. 204: 265-280.

Chaicharn, A. \& W.L. Bullock. 1967. The histopatology of acanthocephalan infections in suckers with observations on the intestinal histology of two catatomid fishes. Acta Zool. 71: 565-586.

Chaudiy, H.S. \& O.P. Kitandelwal. 1961. The anatomy and histology of the alimentary tract of Orienus plagiostomus (Heckel). Ann. Zool. Jap. 34: 139-152.

Chaves, P.T.C. \& C. Vazzoler. 1984. Aspectos biológicos de peixes amazônicos. III Anatomia microscópica do esôfago, estômago e cecos pilóricos de Semaprochilodus isignia (Characiformes, Prochilodontidae). Acta Amazonica 14 (3-4): 343-353.

Clarke, A.J. \& D.M. WitcomB. 1980. A study of the histology and morphology of the digestive tract of the common eel (Anguilla anguilla). Jour. Fish Biol. 16: 159-170.

DALELA, R.C. 1969. Morpho-histology studies of the alimentary tract in the mastocumbelid eel Macrognathus aculeatus. Jour. Zool. Soc. 21: 117-128.

DAwES, B. 1929. The histology of the alimentary canal of the plaice (Pleuronectes platessa). Quant. J. Microsc. Sci. 73: 243-273.

Dzhumaliyev, M.K. 1982. The structure of the epithelium in fishes from different taxonomic groups. Biol. Nauki Kazakh. 11: 65-75.

GAUTHIER, G.F. \& S.C. LANDIS. 1975. The relationship of ultrastructural and cytological features to absorptive activity in the goldfish intestine. Anat. Rec. 172: 675-702.

Godinho, H.; M. Tokumaru \& A.G. Ferri. 1970. Hitologia do trato digestivo de Pimelodus maculatus

Revta bras. Zool. 17 (4): 953 - 971, 2000 
(Lacépède, 1803) (Pisces, Siluroidei). Rev. Brasil. Biol. 30: 583-593.

Grau, A.; S. Crespo; M.C. Sarasquete \& D.M.L. GonZÁl.es. 1992. The digestive tract of the amberjack Seriola dumerili, Risso: a light and scanning electron microscope study. Jour. Fish. Biol. 41: 287-303.

GREENE, C.N. 1912. Anatomy and histology of the alimentary tract of king salmon. Bull. U.S. Bur. Fish. 32: $73-100$.

Groman, D.B. 1982. Histology of the Striped bass. Amer. Fish. Soc. Monogr. No. 3.

HALE, P. 1965. The morphology and histology of the digestive systems of two freshwater teleost Poecilia reticulata and Gasterosterus aculeatus. Jour. Zool. 146: 32-49.

HAMPTON, J.A.; J.E. KLAUNIGN \& P.J. GoldBltT. 1987. Resident sinusoidal macrophages in the liver of the Brown Bullhead (Ictalurus nebulosus): An Ultrastructural, Function and Cytochemical Study. Anat Rec. 219: 338-346.

HAMPTON, J.A.; R.C. LANTZ \& D.E. HINTON. 1989. Functional units in Rainbow trout (Salmo gairdneri, Richardson) Liver: III. Morphometric analysis of parechyma, stroma, and component cell types. Amer. Jour. Anat. 185: 58-73.

HANSEN, S.J. \& N.H. Youson. 1978. Morphology of the epithelium in the alimentary tract of the larval lamprey, Petromyzon marinus. Jour. Morphol. 155: 193-218.

HIRJII, K.N. 1983 Observationson the histology and histochemistry of the esophagus of the perch, Perca Fluviatilis L. Jour. Fish. Biol. 22: 145-152.

Hoar, W.S.; D.J. Randall \& J.R. Brett. 1979. Fish Physiology. Academic Press, Vol. VIII.

HUMBERT, W.; R. KiRSCH \& M.F. MeISTER. 1984. Scanning electron microscopic study of the esophageal mucous layer in the eel, Anguilla anguilla L. Jour. Fish. Biol. 25: 117-122.

KAPOOR, R.; H. SMITH \& I.A. VERIGHINIA. 1975. The alimentary canal and digestion in teleosts. Adv. Mar. Biol. 13: 109-239.

KhanNa, S.S. 1971. Morphology and histology of the teleostean intestine. Anat. Anz. 129: 1-18.

KOROVINA, V.M.; A.V. NEYELOV \& Y.P. BONDARENKO. 1991 The anatomy and histology of the intestine of the Patagonian Toothfish (Dissostichus eleginoides, Smitt). Jour. Ichthyol. 31 (6): 34-40.

Krementz, A.B. \& G.B. ChАpmAN. 1975. Ultrastructure of the posterior half of the intestine of the channel catfish, Ictalurus punctatus. Jour. Morphol. 145: 441-482.

Kristal, J. 1946. The exocrine pancreatic tissue of seven teleosts. S. Afr. Jour. Med. Sci. Biol. Suppl. 11: $79-86$.

KuPERMAN, B.I. \& V.V. Kuz'MAina. 1994. The ultrastructure of the intestinal epithlium in fishes with different types of feeding. Jour. Fish. Biol. 44: 181-193

Langer, M.; S. VAN NoORden \& J.M. Polal. 1979. Peptide hormone-like immunoreactivity in the gastrointestinal tract and endocrine pancreas of eleven teleost species. Cell. Tissue Res. 199: 493-508.

Lima, F.J.A.; F.C.L.B. Lima; M.H. Kireger-Azzolini \& A.C. Boschero. 1991. Topography of the pancreatic region of the Pacu, Piaratus mesopotamicus, Holmberg, 1887. Bol. Tec. CEPTA. 4 (1): 47-56.

Magid, A.M.A. 1975. The epithelium of the gastrointestinal tract of Polypterus senegalus (Pisces, Branchiopteryii). Jour. Morphol. 146: 447-456.

MARTIN, T.J. \& S.J.M. BLABER. 1984. Morphology and histology of the alimentary tracts of Ambassidae (Cuvier) (Teleostei) in relation to feeding. Jour. Morphol. 182: 295-305.

Meister, M.F.; W. HUMBerT; R. KirSCH \& B. VIVIENROEI.S. 1983. Structure and ultrastructure of the oesophagus in sea-water and fresh-water teleosts (Pisces). Zoomorphol. 102: 33-51.

Morrison, C.M. 1987. Histology of the Atlantic Cod, Gadus morhua: Na Atlas. Part one. Digestive Tract and Associated Organs. Canadian Special Publications in Fisheries and Aquatic Science, 98p.

Moshin, S.M. 1962. Comparative Morphology and histology of the alimentary canals in certain groups of Indian teleosts. Acta Zool. 43: 79-133.

MuRRAY, H.M.; G.M. WRIGHT \& G.P. GofF. 1994. A comparative histological and histochemical study 
of the stomach from three species of pleuronectid, the Atlantic halibut, Hippoglossus hippoglossus, the yellowtail flounder, Pleuronectes ferruginea, and the winter flounder, Pleuronectes americanus. Can. Jour. Zool. 72: 1199-1210.

MurRAY, H.M.; G.M. Wright \& G.P. GoFf. 1996. A comparative histological and histochemical study of the post-gastric alimentary canal from three species of pleuronectid, the Atlantic halibut, the yellowtail flounder and the winter flounder. Jour. Fish. Biol. 48: 187-206.

Oliveira-Ribeiro, C.A.; L.M. Fernandes; C.S. Carval.ho; R.I. Cardoso \& N.M. Turcatti. 1995. Acute effects of mercuric chloride on the olfactory epithelium of Trichomycterus brasiliensis. Ecotoxicol. Environ. Saf. 31: 104-109.

Oliveira-Ribeiro, C.A. \& R.F. Torres. 1995. Acute effects evaluation of $\mathrm{HgCl}_{2}$ on epidermis of Trichomycterus brasiliensis. Ecotoxicol. Environ. Saf. 32: 260-266.

Oliveira-Ribeiro, C.A.; J.R.D. Guimarães \& W.C. Pfeiffer. 1996a. Accumulation and distribution of inorganic mercury in a tropical fish. Ecotoxicol Environ Saf. 34:190-195.

Oliveira-Ribeiro, C.A.; E. Fanta; N.M. Turcatti; R.J. Cardoso \& C.S. Carvalho. 1996b. Lethal effects of inorganic mercury on cells and tissues of Trichomycterus brasiliensis. Biocell. 20 (3): 171-178.

Oliveira E SiLVA, S.L. 1971. Contribuição ao estudo histológico da mucosa digestiva de Cichla ocellaris. Arq. Mus. Nac. Rio Janeiro 54: 15-16.

OSMAN, A.H.K. \& T. CACECI. 1991. Histology of the stomach of the Tilapia nilotica (linnaeus, 1758) from the River Nile. Jour. Fish. Biol. 38: 211-223.

PASHA, A. \& S.M. KAMAL. 1964. The anatomy and histology of the alimentary canal of an omnivorous fish, Mystus gulio (Ham.). Proc. Indian Acad. Sci. 59: 211-221.

PICTET, A. 1909. Contribution à pétide histollogique du tube digestif des poassons cyprinoides. Res Suisse Zool. 17: 1-78.

Pignalberi, C.; E.C. Yuan \& Y R. OcChi. 1973. Anatomia y histologia del aparato digestivo de Pimelodus albicans (Val.) Pisces, Pimelodidae. Physis Secc. B Aguas Cont. Org. 32: 297-308.

REIFEL, C.W. \& A.A. TRAVILL. 1977. Structure and carbohydrate histochemistry of the esophagus in tem Teleostean species. Jour. Morphol. 152: 303-314.

Reifel, C.W. \& A.A. TRAVILL. 1979. Structure and carbohydrate histochemistry of the intestine in ten teleostean species. Jour. Morphol. 162: 343-360.

RENNIE, J. 1903. On the occurence of a principal islet in the pancreas of Teleostei (preliminary note). Jour. Anat. Physiol. 37: 375-378

Robertson, J.C. \& R. Bradley. 1992. Liver ultrastructure of juvenile Atlantic Salmon (Samo salar). Jour. Morphol. 211: 41-54.

Rocha, E.; R.A.F. Monteiro \& C.A. Pereira. 1994. The liver of the brown trout, Salmo trutta fario: a ligth and electron microscopy study. Jour. Anat. 185: 241-249.

-1995. Microanatomical organization of hepatic stroma of the brown trout, Salmo trutta fario (Teleostei, Salmonidae): A qualitative and quantitative approach. Jour Morphol. 223: 1-11.

RoGicK, M.S. 1931. Studies on the comparative histology of the digestive tube of certain teleost fishes. Jour Morphol. 53: 1-25.

ROMBOUt, J.K.W.M. \& J.J. TAVERNE-THILE. 1982. An immunocytochemical and electron-microscopical study of endocrine cells in the gut and pancreas of a stomachless teleost fish, Barbus conchonius (Cyprinidae). Cell Tissue Res. 227: 577-593.

SeHgal, P. \& M. SAlaria. 1970. Functional anatomy and histology of the digestive organs of Cirrhina mrigala. Nat. Acad. Sci. 40: 212-222.

Simon, R.C.; A.M. Dollar \& E.A. SMuCKLER. 1967. Descriptive classification on normal and altered histology of trout liver. In: J.E. HAlver \& I.A. Mitchell (Eds). Trout hepatoma research conference papers. U.S. Fish Wildl. Serv. Res. Rep. 70.

SinHA, B.M. 1958. The pancreas in Wallago attu. Sci. Cult. 23: 262-263.

SinHA, B.M. \& S.K. MoITRA. 1974. Morpho-histology of the intestine in a freshwater Major Carp, Cirrhinus mrigala (Ham.) during the different life- history stages in relation to food and feeding 
habits. Anat. Anz. 137: 395-407.

SiRe, M.F. \& J.M. Vernier. 1992. Intestinal absorption of protein in teleost fish. Comp. Biochem. Physiol. 103 (4): 771-781.

Sis, R.F.; P.J. Ives; D.M. Jones; D.H. LewIS \& W.E. HAENSLY. 1979. The microscopic anatomy of the oesophagus, stomach and intestine of the channel catfish, Ictalurus punctatus. Jour. Fish. Biol. 14: 179-186.

SOKOLOV, L.I.; O.V. Koshelev \& G.I. KHALATYAN. 1986. Ecomorphological characteristics of Siberian Stugeon, Acipenser baeri from river. Vopr. Ikhtiol. 5: 741-749.

SRIWASTWA, V.M.S. 1970. Functional anatomy of digestive organs of a fresh-water fish Rhynchobdella aculeata (ham.). Act. Soc. Zool. 34 (2): 136-142.

UlibarRie, L.S. 1982. Histoquimica de las mucinas epiteliais gastrointestinais de Serrasallmus spinopleura (Pisces, Characidae). Res. Assoc. Cienc. Nat. 13: 1-4.

Verma, S.R. \& M.P. TYAGi. 1974. A comparative histological study of the stomach of a few teleost fishes. Gegenbaurs Morphol. Jahrb. 120 (2-5): 244-253.

YADAV, A.N. \& B.R. SingiH. 1980. The gut of an intestinal air-breathing fish, Lepidocephalus guntea (Ham.). Arch. Biol. 91: 413-422.

YasuTAKE, W.T. \& J.H. Wal.ES. 1983. Microscopic Anatomy of Salmonides: An Atlas. United States Department of the Interior, Fish and Wildlife Service, No. 150.

Recebido em 16.IX.1999; aceito em 07.XII.2000. 